\title{
ANALISIS KRITIS PENERAPAN METODE PEMBELAJARAN BERBASIS ONLINE DI MADRASAH IBTIDAIYAH MASA PANDEMI COVID 19 (SOLUSI MENYELAMATKAN MASA DEPAN ANAK-ANAK INDONESIA)
}

\author{
M. Syahrul Ulum \\ IAIN KEDIRI \\ ulumsyahrul.su@gmail.com \\ Jati Pamungkas \\ IAIN KEDIRI \\ jatipamungkas0405@gmail.com
}

\begin{abstract}
Abstrak
Pada tanggal 15 Maret 2020 atau tiga hari setelah Covid-19 ditetapkan sebagai pandemi, Presiden Republik Indonesia mengeluarkan kebijakan bekerja, belajar, dan beribadah dari rumah. Kebijakan tersebut mempunyai arti bahwa semua kegiatan harus berubah orientasinya yaitu tidak boleh melalui tatap muka secara langsung, termasuk di dalamnya adalah kegiatan belajar-mengajar di berbagai jenjang pendidikan baik formal maupun informal. Kegiatan belajar-mengajar tetap berjalan, akan tetapi harus memanfaatkan media berbasis online dengan maksud untuk menghindari penularan Covid-19 di Indonesia. Penelitian ini mengkaji penerapan model pembelajaran berbasis online di jenjang pendidikan Madrasah Ibtidaiyah dengan analisis kritis data level mikro.Hasil dari penelitian ini membuktikan bahwa ada unsur kecanduan teknologi oleh peserta didik untuk disalahgunakan di luar kepentingan pembelajaran. Selain itu, jebakan pendidikan gaya bank telah menjerat proses pembelajaan di mana guru lebih memposisikan diri sebagai subjek dan peserta didik sebagai objek yang hanya bisa menerima begitu saja perintah dari gurunya melalui pemberian tugas mandiri secara terusmenerus dengan sejumlah deadline pengumpulan akhir. Tujuan pendidikan secara umum tetap diarahkan pada pembentukan pribadi yang bermental pembebas, humanis dan demokratis, namun kenyataannya justru menjadikan peserta didik mengalami penindasan akan teknologi pembelajaran.
\end{abstract}

Kata kunci: Madrasah Ibtidaiyah, pembelajaran online, teknologi, analisis kritis

\section{Abstract}

On March 15, 2020 or three days after Covid-19 was declared a pandemic, the President of the Republic of Indonesia issued a policy of work, study, and pray from home. The policy means that all activities must change their orientation, that is, they cannot be face-to-face, including teaching and learning activities at 
various levels of education, both formal and informal. Teaching and learning activities continue to run, but must utilize online-based media intent to avoid Covid-19 transmission in Indonesia. This study examines the application of onlinebased learning models at the Madrasah Ibtidaiyah education with critical analysis of micro level data. The results of this study prove that there is an element of technological addiction by students to be abused outside the interests of learning. In addition, the bank-style education trap has ensured a learning process in which the teacher positions himself as the subject and students as objects that can only take orders from his teacher through continuous independent assignment with a number of final collection deadlines. The purpose of education in general is still directed at the formation of a mentally liberating, humanist and democratic mentality, but in reality it makes students experience oppression of learning technology.

Keywords: Madrasah Ibtidaiyah, online learning, technology, critical analysis

\section{PENDAHULUAN}

Corona Virus Desease 2019 atau Covid-19 ditetapkan sebagai pandemi oleh World Health Organization (WHO) pada tanggal 12 Maret 2020.Dalam keputusannya tersebut WHO menyarankan kepada seluruh negara di dunia untuk bersiap-siap menghadapi Covid19.Di samping menyiapkan penanganan, WHO juga menghimbau agar setiap negara dapat mendeteksi keberadaan Covid-19 di wilayahnya kemudian mencegah supaya tidak menginfeksi luas warga negaranya (WHO, 2020).Pandemi mempunyai arti bahwa Covid19 merupakan virus yang mengancam kesehatan manusia di seluruh dunia. Pada tanggal 15 Maret atau tiga hari setelah Covid-19 ditetapkan sebagai pandemi, Presiden Republik Indonesia mengeluarkan kebijakan bekerja, belajar, dan beribadah dari rumah (Sekretariat Kabinet RI, 2020). Kebijakan tersebut mempunyai arti bahwa semua kegiatan harus berubah orientasinya yaitu tidak boleh melalui tatap muka secara langsung,termasuk di dalamnya adalah kegiatan belajar-mengajar di berbagai jenjang pendidikan baik formal maupun informal. Kegiatan belajar-mengajar tetap berjalan,akan tetapi harus memanfaatkan media berbasis online atau apapun bentuknya asalkan tidak tatap muka secara langsung dengan maksud untuk menghindari penularan Covid-19 di Indonesia. Kebijakan tersebut sebetulnya mempunyai makna untuk melindungi keselamatan generasi bangsa.

Dalam konten hak asasi manusia (HAM),hak yang harus dilindungi adalah hak untuk hidup dan hal-hal yang berkaitan dengan hidup seperti kebebasan berpendapat dan kebebasan berekspresi.Keberlangsungan hidup manusia ditunjang dengan pemenuhan 
kebutuhan primer yaitu makan dan minum.Sesuatu yang melarang atau menghalangi manusia untuk melakukan aktifitas berbicara dan bergerak dapat diartikan sebagai pelanggaran hak asasi manusia.Pada tanggal 10 November PBB mendeklarasikan 30 macam hak asasi manusia termasuk didalamnya terdapat hak atas pendidikan (Zajda dan Ozdowski, 2017: 3).Langkah pemerintah untuk meliburkan kegiatan belajar mengajar di sekolah dengan tatap muka secara langsung merupakan langkah yang tepat karena termasuk melindungi hak untuk hidup.Akan tetapi, tetap melaksanakan kegiatan belajar mengajar di masa pandemi yang berlangsung dalam waktu yang lama juga harus tetap dievaluasi walaupun bagian dari hak atas pendidikan.

Permasalahan yang dihadapi peserta didik di Sekolah Dasar ataupun Madrasah Ibtidaiyah dalam kegiatan belajar berbasis online merupakan suatu tantangan pada masa pandemi ini.Hal tesebut lebih dikarenakan kapabilitas anak-anak yang menjadi peserta didik di sekolah Dasar atau Madrasah Ibtidaiyahdalam menggunakan perangkat elektronik berbasis online walaupun dengan pengawasan ataupun bantuan dari orangtua dalam memperoleh akses pendidikan secara online tentunya berbeda bila dibandingkan dengan jenjang peserta didik di sekolah menengah atau di pendidikan tinggi. Hal tersebut mengacu banyaknya penyalahgunaan gadget oleh anak-anak yang akhirnya menyeret anak-anak pada tindakan kriminalitas ataupun gangguan psikis (Dorothy dan Jerome, 2012: 215).

Sekolah Dasar ataupun Madrasah Ibtidaiah memiliki rentang waktu belajar selama enam tahun dari kelas 1 hingga kelas 6 dan rata-rata diikuti oleh peserta didik berusia 7-13 tahun.Permasalahan mendasar adalah metode pembelajaran berbasis online mempunyai kebutuhan yang berbeda dari kelas 1 hingga 6.Tentu saja hal tersebut juga menuntut seorang guru agar selalu aktif memantau perkembangan peserta didiknya. Pembelajaran online memang memudahkan,akan tetapi hasil dari pembelajaran online tersebut yang harus diuji efektivitasnya.

Berbagai macam corak permasalahan yang kemungkinan bisa timbul lebih banyak akibat penerapan metode pembelajaran di masa pandemi dengan segala pembaharuannya memerlukan konsentrasi yangekstra dari pihak-pihak yang telibat di dalamnya baik pemerintah, guru, orang tua maupun peserta didik itu sendiri.Fenomena yang menjangkiti peserta didik dengan model pembelajaran berbasis online di jenjang pendidikan Sekolah Dasar atau Madrasah Ibtidaiyah perlu untuk dianalisis lebih mendalam.Hal ini tidak terlepas dari masa anak-anak di usiaSekolah Dasar atau Madrasah Ibtidaiyah merupakan saat di mana peserta didik mengukir memori dasar di atas batu, ketika pengalaman hidupnya sudah terukir di batu kehidupan maka akan sulit untuk dihapus. Oleh sebab itu, metode pembelajaran yang diterapkan akan berpengaruhbesar dalam bentuk ukiran tersebut. Penelitian ini tidak memberikan gambaran tentang bagaimana bentuk pembelajaran online yang efektif, tetapi lebih mengarah ke analisis kritis menyangkut 
metode pembelajaran saat pandemi dengan konstruksi sosial peserta didik khususnya di jenjang Madrasah Ibtidaiyah.

\section{METODE PENELITIAN}

Penelitian ini merupakan jenis penelitian kualitatif.Penelitian kualitatif mengutamakan kedalaman penghayatan terhadap interaksi antar konsep yang sedang dikaji secara empiris (Semi, 2012: 11).Sehingga hasil penelitian kualitatif tidak terlepas dari subjektivitas peneliti.Sebagaimana yang dikemukakan oleh Semiawan (2010: 7) bahwa hasil penelitian kualitatif sangat dipengaruhi oleh pandangan, pemikiran, dan pengetahuan peneliti.

Data dalam penelitian ini berupa data primer yang merupakan data yang didapatkan langsung dari sumbernya (Siswantoro, 2005: 63).Data primer dalam penelitian ini adalah wawancara di sejumlah informan penelitian yaitu orang tua siswa dan siswa sendiri.Alasanpemilihan keduanya adalah bahwa mereka merupakan pihak yang terkena dampak langsung dari kebijakan terkait penerapan metode pembelajaran berbasis online saat pandemi, sehingga realitas yang terjadi lebih valid untuk diuji keobjektifannya.Selain wawancara, data primer didapatkan dengan observasi dari sejumlah siswa Madrasah Ibtidaiyah yang terkena dampak penerapan metode pembelajaran saat pandemi.Kemudian dilengkapi dengan studi pustaka dari sumber-sumber referensi terkait teori, metode penelitian, dan bukti penunjang tertulis lainnya.Teknik analisis data yang digunakan dalam penelitian ini adalah teknik deskriptif kualitatif dengan kajian teori kritis ditunjang tahaptahap perkembangan anak terhadap rasionalisasi teknologi sebagai pisau bedah.Penelitian ini dilakukan di Madrasah Ibtidaiyah tepatnya di Madrasah Ibtidaiyah Miftahul Huda Ngreco Kandat Kediri yang telah menerapkan metode pembelajaran berbasis online saat pandemi. Namun, hasil penelitian ini bisa digunakan sebagai kritik model pembelajaran secara lebih luas ke Madrasah Ibtidaiyah lainnya yang tentunya memiliki karakteristik dan sistem yang sama dengan lokus penelitian yang dikaji.

\section{HASIL PENELITIAN DAN PEMBAHASAN}

\section{A. Teori Sosial Kritis}

Model analisis kritis ini mengacu pada teori sosiologi kritis (critical sociology)yang berkembang di Frankfurt Jerman mulai dekade 1920-an. Pada awal kelahirannya teori sosiologi kritis menggaungkan kritik kepada pemerintah Nazi di Jerman yang melakukan penindasan-penindasan kepada masyarakat. (Adiwikarta, 2016:53). Secara akademis, Ritzer (dalam Adiwikarta, 2016:54) mengemukakan bahwa sosiologi kritis pada perkembangan selanjutnya mengkritik: pertama sosiologi yang tidak konsisten membela kaum lemah, kedua Neo Marxis yang determinisme ekonomi, ketiga positivisme yang 
menerapkan metode sains untuk semua ilmu, keempat masyarakat modern yang menerapkan rasonalisme teknologi secara tidak berpihak kepada rakyat kecil, kelima industri budaya yang memberikan harapan palsu.

Model analisis pendidikan yang bersandar pada teori sosiologi kritis mendorong emansipasi kaum lemah yang tersisihkan dalam masyaraat. Hal yang menjadi fokus utamanya adalah memperbaiki peristiwa-peristiwa aktual dalam pendidikan, baik pada level makro ataupun mikro yang dinilai kurang memperhatikan kaum lemah yang memerlukan bantuan. (Adiwikarta, 2016: 54).

Pada penelitian ini jenis teori sosial kritis yang digunakan lebih berada pada tataran level mikro dengan diperkuat dari sisi makro untuk memperdalam analisis data. Level mikro di sini terletak pada pembahasan hubungan antara guru dan peserta didik terkait dengan penerapan model pembelajaran berbasis online melalui pemanfaatan teknologi saat pandemi Covid-19. Data kemudian diperkuat dengan level makro yang diambilkan dari kebijakan pemerintah terkait keberadaan sarana dan prasarana pendukung sistem pembelajaran jarak jauh berbasis online.

\section{B. Tahap Pengembangan Diri (Self) Manusia G.H. Mead}

Di dalam buku mind, self, and society, Mead menjelaskan tahap pengembangan diri (self) manusia. Asumsi dari penggunaan pemikiran Mead ini selain memakai pisau bedah teori sosial kritis adalah bahwa penelitian ini dikaitkan dengan pembahasan level mikro yang lebih difokuskan pada perkembangan proses belajar peserta didik di Madrasah Ibtidaiyah. Artinya titik tekan pada analisis ini terletak pada tindakan individu peserta didik yang diakibatkan oleh penerapan model pembelajaran berbasis online.

Tahap pengembangan diri (self) manusia dijelaskan oleh Mead (dalam Damsar, 2015: 40) yaitu ketika manusia lahir dia belum memiliki diri. Diri manusia berkembang secara bertahap melalui interaksi dengan orang lain. Pengembangan diri manusia berlangsung melalui beberapa tahap, yaitu pertama tahap play stage, seorang anak belajar mengambil perspektif orang lain yang dianggap sesuai dengan kebutuhan hidupnya dan melihat dirinya sebagai objek. Kedua, tahap pertandingan (game stage) seorang anak tidak hanya mengetahui peran yang dimainkannya melainkan juga peran yang harus dimainkan orang lain dengan siapa dia melakukan interaksi dan ketiga tahap the generalized other, pada tahap ini seorang anak mengontrol perilakunya sendiri menurut peran-peran umum yang bersifat impersonal.

Begitu kompleksnya tahap perkembangan diri manusia yang diawali dari masa anak-anak sangat menarik untuk dibahas.Di sinilah pendidikan memiliki arti penting bagi diri anak untuk mulai membentuk identitas dirinya. Dari pendidikan anak diajari cara bersosialisasi, ditanamkan pengetahuan, dan pembentukan karakter diri. Oleh karena itu, 
sangat menentukan juga dengan jenis pendidikan apa yang dipilih, hingga akhirnya bisa membentuk jati diri seorang anak. Model pembelajaran yang diterapkan di jenjang pendidikan khususnya di Madrasah Ibtidaiyah di sini memiliki porsi lebih untuk dianalisis dan dikritisi dengan dihubungkan fenomena ketidaknomalan pendidikan (pembelajaran online) masa pandemi Covid-19 dengan tindakan peserta didik selanjutnya secara kritis melalui kajian teori sosial kritis.

C. Efektivitas Pembelajaran Berbasis Online

Efektivitas pembelajaran dipengaruhi oleh komunikasi antara guru dengan murid dan juga ditunjang oleh sesama peserta didik yaitu komunikasi antara murid dengan murid. Pembelajaran berbasis online memang terdapat komunikasi yang intens jika dikembangkan, akan tetapi manusia sebagai makhluk sosial tetap membutuhkan dimensi komunikasitatap muka secara langsung. Pada peserta didik di Madrasah Ibtidaiyah, komunikasi secara langsung antara guru dan murid dapat mempengaruhi perkembangan belajar secara signifikan karena seorang guru dapat melihat perkembangan peserta didiknya secara langsung dan aktual.Interaksi sosial yang terjadi di kelas juga mempengaruhi kemampuan sosial peserta didik.Kelemahan komunikasi guru dengan murid disini dapat ditutupi oleh pengawasan orangtua dan juga kemampuan orangtua dalam materi pembelajaran. Akan tetapi, orangtua juga mempunyai keterbatasan waktu dan bahkan pengetahuan.Hal itu menjadikan kendala baru bagi perkembangan belajar peserta didik.

Efektivitas pembelajaran berbasis online dipengaruhi oleh tingkat kemampuan dalam penguasaan teknologi untuk mengoptimalkan proses belajar. Dalam hal tersebut seorang guru harus mempunyai wawasan dan juga keahlian teknologi sebelum menentukan metode pembelajaran online yang dipilih. Pemilihan metode pembelajaran seharusnya dan idealnya harus melibatkan audio dan visual karena peserta didik Madrasah Ibtidaiyah masih membutuhkan arahan pendidikan yang bersifat audio visual agar pembelajaran bersifat seperti layaknya sebelum pandemi yaitu peserta didik dapat melihat dan mendengarkan arahan gurunya secara langsung dan aktual (Sudarsana dkk., 2020: 67). Pembelajaran online audio visual misalnya lewat zoommeeting atau google meet merupakan pilihan yang tepat,akan tetapi kelemahannya adalah dibutuhkan kapabilitas kuota internet yang cukup besar. Jika hal tersebut berulang setiap hari dan dalam tempo yang lama pasti akan menimbulkan dampak negatif khususnya bagi keluarga menengah ke bawah dan juga terdampak Covid-19. Hasil dari pengamatan dari lingkungan peneliti menunjukkan bahwa metode yang digunakan guru tidak selalu berbasis online artinya peserta didik diberi tugas untuk mengerjakan soal-soal di buku yang diberikan oleh gurunya dan orangtua mengawasi.Artinya tidak setiap hari pembelajran online dilakukan.Jadi sebetulnya guru juga mempunyai keterbatasan dalam menggunakan 
teknologi pembelajaran berbasis online atau juga dapat diartikan bahwa keluarga peserta didik juga mempunyai keterbatasan dalam pembelajaran berbasis online.

Pembelajaran berbasis online dalam hal tertentu dapat menyebabkan masalah bagi peserta didik yaitu munculnya sifat malas untuk membaca buku.Hal tersebut terjadi karena peran alat komunikasi yang dapat mendownload buku-buku tanpa harus mengeluarkan biaya lebih. Selain hal tersebut, peserta didik dengan minimnya pengawasan akan mudah terpikir oleh mereka untuk mengerjakan tugas atau pekerjaan mereka dengan cara copy paste. Padahal dalam dunia pendidikan kejahatan besar adalah tindakan plagiat.Kemudian kelemahan pembelajaran berbasis online adalah sifatnya yang jarak jauh, sehingga dapat menyebabkan peserta didik lebih individualis dan menjauhkan diri mereka sebagai makhluk sosial (Switri, 2019: 20).

Dari penjelasan tersebut di atas dapat dipahami bahwa pembelajaran berbasis online tidak ideal bagi peserta didik di Madrasah Ibtidaiyah karena tidak ada pengawasan dari guru secara langsung dan terus menerus seperti halnya di kelas.Minimnya komunikasi guru dengan murid sangat mempengaruhi perkembangan belajar.Ruh dari pembelajaran berbasis online adalah metode pembelajarannya sendiri.Banyak kasus terjadi di lapangan bahwa pembelajaran online tidak sepenuhnya dijalankan karena faktor penguasaan teknologi oleh tenaga pendidik serta kemampuan ekonomi keluarga peserta didik dalam mengikuti pembelajaran berbasis online.Jadi, pembelajaran online sebetulnya sebagai pelengkap dalam belajar dan tidak dapat dijadikan senjata utama dalam meningkatkan perkembangan belajar peserta didik di Madrasah Ibtidaiyah.

D. Kesiapan Informasi dan Teknologi

Menurut Alisyahbana (1980) Teknologi telah dikenal manusia sejak jutaan tahun yang lalu karena dorongan untuk hidup yang lebih nyaman, lebih makmur dan lebih sejahtera. Jadi sejak awal peradaban sebenarnya telah ada teknologi, meskipun istilah teknologi belum digunakan. Istilah teknologi berasal dari "techne" atau cara dan "logos" atau pengetahuan. Jadi secara harfiah teknologi dapat diartikan pengetahuan tentang cara. Pengertian teknologi sendiri menurutnya adalah cara melakukan sesuatu untuk memenuhi kebutuhan manusia dengan bantuan akal dan alat, sehingga seakan-akan memperpanjang, memperkuat atau membuat lebih ampuh anggota tubuh, pancaindra, dan otak manusia.

Keberadaan informasi dan teknologi di masa pandemi merupakan hal mutlak yang harus dipersiapkan demi menyukseskan himbauan pemerintah untuk belajar dari rumah.Pembelajaran berbasis online di masa pandemi sebetulnya terdapat banyak masalah yang harus diketahui dan dipelajari karena hal itu menyangkut kesiapan dan efektivitas pembelajaran online.Pertama adalah keadaan sekolah, maksudnya di Indonesia terdapat dua kategori sekolah dilihat dari minat siswa sebelum dilakukan sistem zonasi yaitu sekolah favorit dan sekolah semenjana.Sekolah favorit mempunyai fasilitas yang lengkap, 
mayoritas guru yang di atas rata-rata terlebih tentang penguasaan informasi dan teknologi, dan mayoritas keadaan ekonomi keluaraga peserta didik merupakan masyarakat menengah ke atas.Melihat data di atas peserta didik di sekolah favorit di sekolah dasar ataupun ibtidaiyah tentu dapat melaksanakan pembelajaran online sesuai dengan harapan.Sekolah yang semenjana mungkin harus diperhatikan karena kategori kemampuan guru dan keadaan ekonomi keluarga pesera didik kurang mendukung.Jadi, ketika pembelajaran online di masa pandemi lebih mengedepankan tetap berlangsungnya pembelajaran hingga akhir semester dan bukan mengejar kualitas pendidikan. Jadi fakta keberadaan sekolah di Indonesia sebetulnya dapat dijawab dengan analisa-analisa sederhana bahwa kualitas pendidikan menurun di masa pandemi karena kesiapan proses belajar-mengajar di lapangan memang terbatas.

Hal kedua adalah geografis Indonesia, maksudnya hal tersebut terkait dengan kekuatan sinyal dan akhirnya mempengaruhi keterbatasan dalam akses internet.Keterbatasan tersebut sudah tentu mengganggu pembelajaran berbasis online (Sudarsana, 2020:47).Jika kita berbicara komunikasi di kota-kota besar sudah tentu sinyal bukan lagi sebuah masalah.Artinya di kota-kota besar pembelajaran berbasis online sangat layak.Di Indonesia sendiri juga mengenal istilah Jawa dan non Jawa. Rata-rata di Pulau Jawa tidak ada kendala serius dalam komunikasi kecuali memang daerah terpencil dan kendala teknis wilayah seperti wilayah yang dikelilingi bukit atau gunung. Kenyataannya prasarana komunikasi di Indonesia memang tidak rata.Indonesia memiliki banyak sekali pulau-pulau kecil yang berpenghuni dan dalam pulau tersebut juga terdapat sarana pendidikan minimal sekolah dasar.Pertanyaan besarnya adalah mampukah daerah-daerah terpencil dan pelosok di Indonesia menjawab tantangan pemerintah untuk belajar dari rumah. Tentu saja kebijakan tersebut harus dievaluasi mengingat sebaran virus memang berbeda dari daerah satu dengan yang lain.

Pembelajaran berbasis online yang efektif juga harus menakar tingkat ekonomi keluarga peserta didik.Pembelajaran berbasis online pada saat ini sangat efektif jika menggunakan handphonedaripada media elektronik lainnya.Masalahnya adalah ketersediaan dan kemampuan handphone keluarga peserta didik apakah memadai.Kemudian masalah kuota atau paket untuk mengaktifkan internet juga harus dikalkulasi dengan tepat karena kuota tidak gratis atau akses pemerintah untuk menggratiskan internet memang sangat kurang optimal.Idealnya keputusan belajar di rumah harus diikuti oleh data-data lapangan untuk melancarkan pelaksanaan pembelajaran berbasis online untuk peserta didikMadrasah Ibtidaiyah.Data-data tersebut dipakai untuk acuan pemberian bantuan pemerintah kepada peserta didik di sekolah dasar ataupun Madrasah Ibtidaiyah yang mengalami kesulitan dalam pemenuhan pelaksanaan pembelajaran online.Hal ini harus dibaca secara cermat oleh pemerintah melalui 
kementerian pendidikan.Dalam hal ini yang menjadi korban adalah peserta didikbeserta orang tuanya dari masyarakat menengah ke bawah dalam pemenuhan pembelajaran berbasis online. Alat komunikasi berupa handphone yang dapat digunakan pembelajaran online terbatas danbahkan harus berbagi dengan orangtua ataupun kakak atau adiknya yang juga mengikuti pembelajaran online adalah masalah yang tidak dapat diremehkan.

Selain alat komunikasi, masalah pendapatan orangtua peserta didik juga harus diperhatikan.Jika orangtua peserta didik tersebut merupakan pekerja harian dan itupun terdampak Covid-19, maka pemenuhan pembelajaran berbasis online semakin sulit untuk diwujudkan.Selain masalah tersebut internet gratis yang tersedia di ruang-ruang publik di desa juga sangat minim bahkan ada yang tidak tersedia.Hal tersebut semakin membuat pembelajaran berbasis online mustahil dilakukan oleh peserta didik dari keluarga yang menengah ke bawah dan ditambah oleh faktor geografis yang terpencil (Sudarsana, 2020: 71). Solusinya ada satu yaitu kegiatan belajar dilakukan dengan cara pemberian tugas secara terus menerus oleh guru. Jadi, pemerintah harus peka dan mengerti betul kendalakendala pembelajaran berbasis online.Pembelajaran berbasis online merupakan sebuah metode yang terlalu dipaksakan ataukah memang memenuhi kebutuhan hak belajar para peserta didik khususnya di sekolah dasar ataupun Madrasah Ibtidaiyah.

\section{E. Beban Psikis Peserta Didik}

Proses belajar yang tidak normal karena berbagai faktor dapat berpotensi terjadinya stres pada peserta didik. Peserta didik di sekolah dasar maupun Madrasah Ibtidaiyah merupakan masa emas dalam mengembangkan kemampuan akademik.Jadi,peserta didik harus dijauhkan dari hal-hal yang menghambat perkembangan akademik misalnya tekanan atau stres, diskriminasi, dan bullying (Ariobimo, 2008:8-10).Pembelajaran pada masa pandemi merupakan salah satu faktor tidak normal pada proses belajar karena dapat memunculkan masalah pada psikis peserta didik diMadrasah Ibtidaiyah. Masalah psikis muncul dikarenakan pola pembelajaran yang didominasi oleh tugas-tugas yang diberikan oleh guru. Tugas-tugas belajar yang tidak pernah dikerjakan seperti proses belajar secara normal sebelum pandemi Covid-19. Tugas-tugas yang menumpuk di buku tugas serta tidak diketahui sampai kapan berakhir pembelajaran berbasis online merupakan pertanyaan besar yang terdapat di beban peserta didik serta orangtuanya.Suasana sosial dengan temanteman di sekolah juga merupakan hal yang dirindukan oleh peserta didik di Madrasah Ibtidaiyah.Pada dasarnya suasana di sekolah adalah sesuatu hal yang dirindukan karena manusia tercipta sebagai makhluk sosial.Semakin lama manusia mengurung diri di rumah untuk selamat dari pandemi Covid-19 pada akhirnya pada titik tertentu manusia ingin keluar dari rumah untuk menikmati hidup yang sesungguhnya.Penemuan vaksin untuk Covid-19 juga belum menemukan titik terang. 
Peserta didik di Madrasah Ibtidaiyah pada dasarnya ingin merasakan libur panjang di suasana belajar yang normal.Pada masa pandemi sekarang ini yang hadir adalah fakta sebaliknya.Pembelajaran berbasis online secara waktu yang lama dan kehidupan sosial dengan dunia luar terkunci membuat para peserta didik kehilangan semangat belajar.Kehilangan semangat belajar di masa pandemi muncul karena dua faktor yaitu metode pembelajaran berbasis online yang monoton yaitu pemberian tugas secara terus menerus dan cenderung tidak ada timbal balik antara guru dengan murid menyebabkan peserta didik di Madrasah Ibtidaiyah menjadi bosan. Hal tersebut sangat terlihat pada peserta didik di kelas 1 dan 2 karena basis belajar peserta didik di kelas tersebut memang harus terdapat adanya bimbingan guru secara terus menerus dan disertai dengan belajar dengan cara yang menyenangkan.

Dengan demikian, posisi teknologi yang dalam hal ini adalah handphone sebagai alat penunjang utama dalam proses pembelajaran berbasis online berada pada posisi "proses" dan "hasil". Dikatakan proses hal ini disebabkan oleh adanya pihak yang dapat menguasai teknologi tersebut (guru) untuk memberikan teknik pembelajaran yang menjadi maksud sebenarnya. Pihak-pihak yang berkuasa tersebut mempunyai kemampuan untuk memanfaatkan dan memiliki tujuan dari pemanfaatan teknologi tersebut,akan tetapi peserta didik tidak akan pernah mengetahui secara pasti tujuan sebenarnya dari metode pembelajaran tersebut. Peserta didik hanya mengetahui jika mereka mampu mengerjakan tugas-tugas rumah yang diberikan oleh guru dengan baik, maka akan memperoleh nilai sempurna dan begitu pula sebaliknya. Teknologi dalam hal ini benar-benar telah menjadi alat yang justru "menindas" kebebasan belajar. Waktu yang sebenarnya bisa untuk dibagi dengan kegiatan lain di luar tugas sekolah seperti bermain, bersosialisasi, belajar di Madrasah Diniyah, dan istirahat yang cukup menjadi tergerus dengan adanya tugas-tugas rumah tiada henti yang selalu dikejar-kejar oleh deadline pengumpulan terakhir.Pada posisi hasil ini dikaitkan dengan peserta didik yang tidak punya kuasa atas penguasaan teknologi, sehingga cenderung mudah menerima dan setuju atas segala macam penugasannya.

Dominasi teknologi sebagai kekuatan yang makin berpengaruh dalam mengendalikan peri kehidupan manusia dan kemanusiaan itu oleh sejumlah filsuf akhir abad ini disebut sebagai gejala teknokrasi.Keterbiasaan manusia modern untuk hidup "bergandengan" dengan teknologi hampir menjadi ketergantungan.Peserta didik di jenjang pendidikan Madrasah Ibtidaiyah seakan-akan dipaksa untuk segera menjadi manusia modern yang sebenarnya masih asing bagi kehidupannya.Teknologi dan manusia modern adalah dwitunggal yang tak terpisahkan, akibatnya melihat dunia baru yang dirasa lebih menyenangkan dengan penggunaan handphone sebagai sarana pembelajaran justru menjadikan peserta didik kecanduan. Alat komunikasi yang canggih dengan segala macam fitur canggihnya akan sangat mengasyikkan bila dibandingkan dengan literasi cetak. 
Handphone yang dimaksud untuk memperlancar proses pembelajaran jarak jauh menjadi disalahgunakan untuk game, chat, dan pemanfaatan fitur lainnya yang semakin tidak mengenal waktu.

Kiranya tidak berlebihan untuk menyatakan bahwa teknologi dan teknokrasi niscaya akan membawa perubahan pula dalam gaya hidup manusia dan masyarakat modern. Jika demikian halnya, maka tidak keliru pula untuk menyatakan bahwa dominasi teknologi dan teknokrasi akan berlanjut dengan berseminya budaya baru yang melahirkan berbagai nilai baru pula yang cenderung menjadi acuan perilaku manusia modern dalam berbagai pola interaksi dengan sesamanya.

Perubahan metode pembelajaran berbasis online dengan pemberian tugas mandiri secara terus menerus merupakan permasalahan baru bagi peserta didik yang duduk di jenjang Madrasah Ibtidaiyah.Hal ini tentunya berdampak bagi pola pembentukan konsep diri dari metode pembelajaran tatap muka langsung ke metode daring.

Meminjam konsep Mead tentang konsep diri terdapat hal penting yang layak untuk dianalisis yaitu hubungan timbal balik antara diri sebagai "objek" dan diri sebagai "subjek". Diri sebagai objek ditunjuk Mead dengan konsep " $m e$ ". Diri sebagai subjek yang bertindak ditunjukkan dengan konsep " $P$ ". " $I$ " merupakan aspek diri yang bersifat nonreflektif. Dia tidak mencakup ingatan-ingatan dari tindakan-tindakan masa lampau atau antisipsi di masa yang akan datang. Artinya adalah diri sebagai subjek yang bertindak (" $I$ ") ada hanya dalam detik sekarang ini.Namun, begitu suatu tindakan dilaksanakan, ingatan tentang tindakan itu lalu menjadi bagian dari "me" dalam konsep diri itu.(Johnson, 1986: 18).

Mead juga menyebutkan seseorang dalam membentuk konsep dirinya akanmengambil perspektif orang lain dan melihat dirinya sendiri sebagai objek. Untuk itu,ia melewati tiga tahap perkembangan diri, yaitu fase play stage, game stage, dan generalized other. (Wirawan, 2012: 126). Ketiga fase tersebut akan dialami secara langsung oleh setiap orang tidak terkecuali peserta didik di bangku Madrasah Ibtidaiyah. Setiap peserta didik akan menjalani ketiga fase perkembangan diri secara bertahap sesuai dengan tingkatan usia. Namun, permasalahan di sini bukanlah pada aspek dimana posisi diri itu sebagai subjek atau objek. Keduanya sama dan saling berkaitan, hanya yang perlu untuk didalami lebih lanjut adalah proporsi antara diri sebagai subjek " $I$ " dan diri sebagai objek " $m e$ ".

Proses pembentukan konsep diri secara proporsional adalah manakala terdapat keseimbangan antara diri sebagai subjek dan objek. Dalam proses penerapan metode pembelajaran berbasis online saat pandemi Covid-19 yang justru terkesan dilakukan secara monolog dari guru ke peserta didik dengan pemberian tugas mandiri secara terus menerus merupakan titik awal terjadinya ketimpangan dalam proses pembentukan konsep diri. 
Idealnya " $m e$ " yang merupakan organisasi diri berisi sikap orang lain sebagai panduan bagi tingkah laku menjadi berlebihan. Peserta didik akan merasa dihantui oleh tugas-tugas rumah yang tiada henti, padahal tugas rumah itu bukanlah murni keinginannya melainkan kegiatan yang diberikan oleh gurunya. Sehingga, peserta didik yang ingin bebas dengan memunculkan sisi subjek dirinya semakin terkikis, proses sosialisasi dengan teman sebaya, tetangga, maupun saudara menjadi tergerus dengan hanya terkurung di dalam kamar. Tidak ada hubungan dialogis antara guru-orang tua atau guru-peserta didik dengan kegiatan ini, hanyalah nilai angka yang menjadi tolok ukurnya, bukan pada proses menjadi (becaming) yang terus menerus mencari sebuah eksistensi.

Apa yang dilakukan oleh peserta didik selama ini adalah hasil konstruksi realitas belaka dari orang lain. Mereka disetir, diatur, kemudian dibentuk oleh subjek lain dengan memanfaatkan teknologi, lebih tepatnya adalah menjadi objek dari teknologi. Hemat kata metode pembelajaran berbasis online dengan memberikan tugas mandiri kepada peserta didik di jenjang Madrasah Ibtidaiyah tanpa disertai dengan hubungan dialogis antara gurupeserta didik maupun orang tua adalah pengejawantahan dari pendidikan gaya "bank modern" dengan guru sebagai "subjek" dan murid sebagai "objek". Jika hal tersebut tidak segera diatasi, maka peserta didik hanya akan menjadi robot yang dikontrol oleh remote teknologi.

Perubahan metode pembelajaran jarak jauh melalui media berbasis online jika dianalisis secara kritis memang hal tersebut merupakan usaha manusia yang seperti dikatakan oleh Sindhunata (1982) dalam bukunya "Dilema Usaha Manusia Rasional" menunjuk sebagai produk unggul dari manusia rasional. Rasional di sini berarti bisa diterima akal oleh cara pandang manusia modern. Hal itulah yang menjadi pertanyaan besar, sampai-sampai dengan meminjam istilah Sindhunata adalah sebagai usaha manusia "rasional yang irrasional", rasional yang sebenarnya tidak rasional. Tidak rasional dikarenakan ternyata terdapat hal lain yang berdampak lebih parah yang ditimbulkan daripada hanya mengonsumsinya semata. Peserta didik telah kehilangan dunia yang sebenarnya.

F. Kritik Pendidikan Gaya Bank

Dalam fenomena metode pembelajaran berbasis online di tingkat Madrasah Ibtidaiyah yang dilakukan selama pandemi Covid-19 ini seorang guru lebih cenderung memposisikan dirinya sebagai subjek aktif, sedangkan peserta didik sebagai objek pasif yang penurut dan diperlakukan sama dari realitas dunia yang diajarkan kepada mereka sebagai objek teoritis dari ilmu pengetahuan yang tidak berkesadaran. Hal tersebut sangat mirip dengan istilah pendidikan gaya bank yang pernah dikritik oleh pemerhati pendidikan Paulo Freire. 
Konsep pendidikan "gaya bank" adalah model pembelajaran dalam pendidikan yang hanya satu arah (monologis) (Harir, 2015). Asumsinya bahwa ilmu pengetahuan adalah sebuah anugerah yang dihibahkan oleh guru yang menganggap dirinya berpengetahuan kepada peserta didik yang dianggap tidak memiliki pengetahuan apa-apa. Menganggap bodoh secara mutlak pada orang lain. Hal itu menunjukkan sebuah ciri dari ideologi penindasan, yang berarti mengingkari pendidikan dan pengetahuan sebagai proses pencarian jati diri manusia seutuhnya.

Realitas tersebut kemudian membawa guru dalam anggapan bahwa peserta didik adalah objek yang tidak berkesadaran, senantiasa pasif dan menerima apasaja yang diberikan oleh guru. Seorang guru dalam pendidikan gaya bank terkadang tidak sadar bahwa ia telah melakukan aksi "dehumanisasi". Ia juga tidak memahami bahwa pengetahuan yang ditanamkan kepada peserta didik berisi kontradiksi dengan realitas. Pengetahuan yang ditanamkan kepada peserta didik tidak beriringan dengan hasil pembacaannya terhadap realitas sehingga memunculkan kontradiksi pemahaman (Dzakiri, 2000:50).

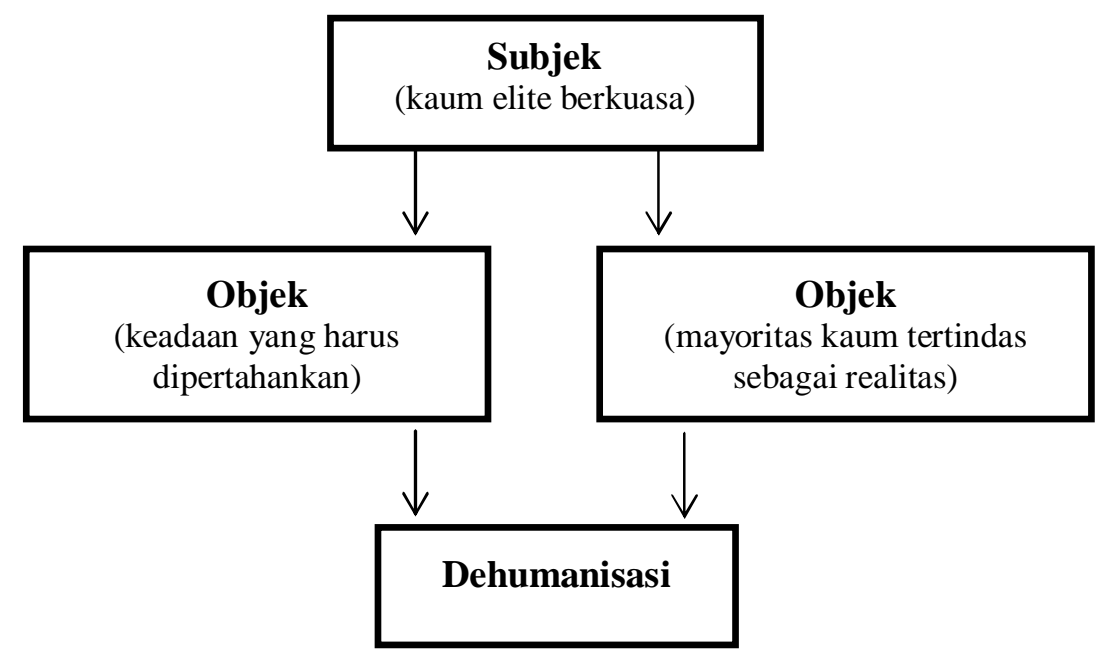

Skema 1: konsep metode anti-dialogis (sumber: Umiarso dan Zamroni, 2011: 164)

Dalam konsepsi pendidikan Paulo Freire, kontradiksi dari pendidikan gaya bank adalah pendidikan "hadap masalah" (Freire, 2008). Pendidikan hadap masalah sebagai pendidikan pembebasan menegaskan manusia sebagai makhluk yang berproses menjadi (becoming) sebagai sesuatu yang tidak pernah selesai dan terus menerus mencari sebuah eksistensi.Pendidikan hadap masalah menjawab kontradiksi antara guru dengan peserta didik dengan situasi pendidikan yang berlangsung secara dialogis (Umiarso dan Zamroni, 2011: 161).Dalam konsep ini guru tidak hanya berposisi sebagai pengajar, tetapi juga diajar melalui dialog dengan peserta didiknya.Sehingga Freire dalam sistem pendidikan hadap masalah ini menekankan pada metode yang disebut "pendidikan dialogis" tempat 
terdapat dinamika dialektik antara pendidik (guru) dengan peserta didik. (Sholeh dalam Umiarso dan Zamroni, 2011: 162)

Pendidikan yang berjalan dua arah ini senantiasa menempatkan peserta didik sebagai "sahabat" dalam proses belajar mengajar. Sebagai sahabat perlu untuk didengarkan dan diperhatikan dari segala macam keinginannya. Dalam pendidikan yang bersifat dialogal tidak lagi menempatkan seorang guru sebagai subjek yang menentukan semuanya sedangkan murid sebagai objek pasif dan tinggal menerima segala apa yang telah diberikat oleh guru (Azzet, 2017: 37). Guru yang mengabaikan dialog dalam proses pendidikan yang diampunya biasanya juga berpandangan bahwa tugasnya hanya mengajar atau mendidik, bukan mendampingi peserta didik dalam proses belajar (Azzet, 2017: 62). Posisi peserta didik hanya sebagai objek yang harus siap untuk dibawa ke mana saja dalam proses pendidikan yang dilakukan oleh sang guru.

Pendidikan dalam konsep dialogis ini, guru dengan peserta didik saling belajar satu sama lain saling memanusiakan. Dalam proses ini guru mengajukan bahan untuk dipertimbangkan oleh peserta didik, kemudian pertimbangan guru diuji kembali setelah dipertemukan dengan pertimbangan peserta didik begitu juga sebaliknya. Hubungan keduanya pun menjadi "subjek-subjek", bukan subjek-objek.Objek yang sebenarnya bagi keduanya adalah realita itu sendiri.Dengan demikian, terciptalah suasana dialogis yang intens dan bersifat intersubjek untuk memahami suatu objek bersama. Freire menggambarkan suasana dialogis dengan skema sebagai berikut:

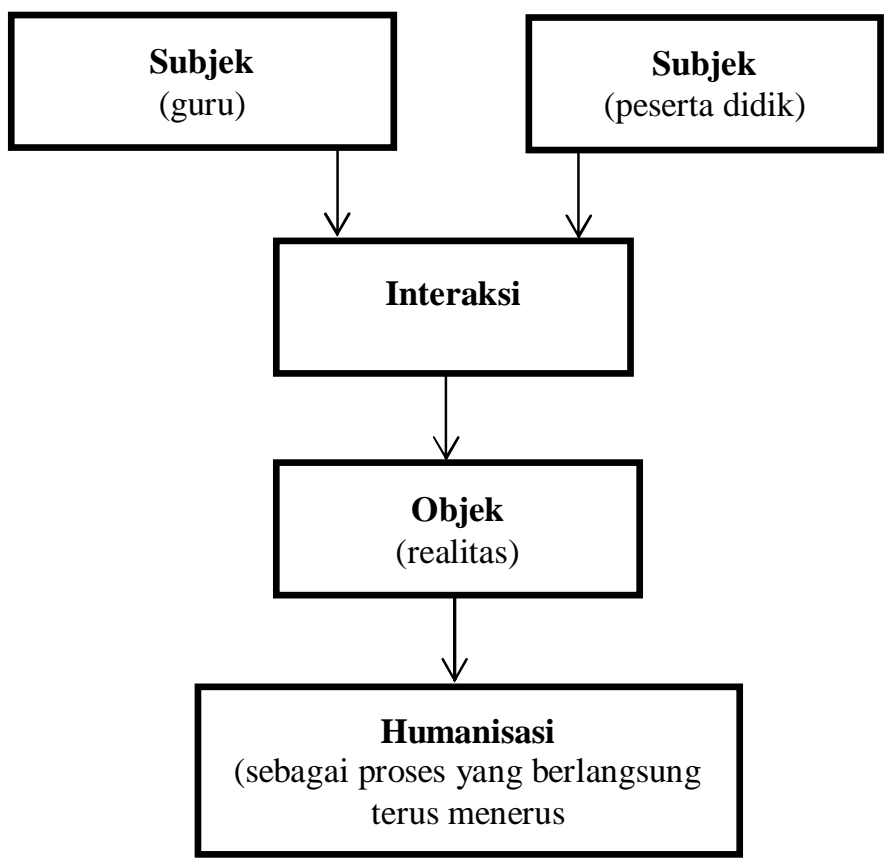

Skema 2: konsep metode dialogis Paulo Freire (sumber: Umiarso dan Zamroni, 2011: 163) 
Dialog menurut Freire merupakan bagian dari kemanusiaan historis dalam menjadi manusia. Oleh sebab itu, dialog adalah postur yang niscaya bagi manusia untuk menjadi makhluk yang komunikatif-kritis. Dialog adalah momen untuk merefleksikan realitas yang diciptakan dan dibuat ulang oleh manusia (Shor dan Freire dalam Umiarso dan Zamroni, 2011: 164).

\section{G. Solusi Alternatif Pemecahan Masalah}

Pembelajaran berbasis online merupakan keniscayaan yang harus dilaksanakan,akan tetapi harus melihat kemampuan sumber daya manusia peserta didik. Secara makro bantuan pemerintah sangat mutlak diperlukan untuk peserta didik khususnya di Sekolah Dasar ataupun Madrasah Ibtidaiyah agar mampu mengikuti pembelajaran berbasis online.Pemerintah harus mempunyai keberanian untuk mempertaruhkan ekonominya untuk membantu seperti akses internet gratis secara masif dan berkala dan pemberian alat komunikasi yang memadai karena kedua elemen tersebut adalah kunci pembelajaran berbasis online agar tercipta keadilan pemenuhan hak pendidikan pada masa pandemi Covid-19.

Solusi lainnya adalah harus ada keberanian untuk menyelamatkan generasi penerus bangsa termasuk peserta didik sekolah dasar ataupun Madrasah Ibtidaiyah. Cara menyelamatkan adalah menurunkan kasus Covid-19 di Indonesia secara signifikan, kalau tidak ada progres penurunan maka pembelajaran berbasis online dapat diteruskan dengan ketentuan semua peserta didik khususnya peserta didik di Sekolah Dasar ataupun Madrasah Ibtidaiyah secara keseluruhan dapat mengikuti pembelajaran berbasis online tanpa ada hambatan berupa hal-hal teknis seperti tidak adanya alat komunikasi, akses internet yang susah, tidak adanya internet gratis, serta metode pembelajaran yang tidak online, atau fiktifnya pembelajaran berbasis online.

Jika pembelajaran berbasis online sebenarnya sulit atau bahkan fiktif, maka pemerintah dapat mengambil langkah yang berbaik untuk menyelamatkan masa depan generasi penerus bangsa. Langkah yang ditawarkan adalah kegiatan belajar mengajar harus ditunda di level pendidikan bawah agar terlebih dahulu pemerintah fokus dalam menurunkan angka penyebaran Covid-19. Keputusan penghentian belajar online dengan belajar tatap muka secara langsung dengan menggunakan skenario protokol kesehatan juga sangat riskan untuk dilakukan karena hal ini berhubungan dengan seberapa mampukahpeserta didikuntuk hidup disiplin.Jadi, solusi alternatifnya adalah mencoba menggeser tahun ajaran dari Juli menjadi Januari. Januari tahun 2021 merupakan waktu yang tepat untuk melaksanakan kegiatan belajar mengajar di level pendidikan bawah secara langsung atau tatap muka. Pada bulan Juni hingga Desember 2019 pemerintah 
diharapkan dapat fokus menurunkan secara signifikan kasus Covid-19 di Indonesia sambil membuat atau menunggu tersedianya vaksin. Logika pemikiran yang dibangun adalah menjaga keberlangsungan hidup adalah hal utama dan keberlangsungan hidup itulah dapat dilakukannya pemenuhan hak atas pendidikan.

Sedangkan analisis solusi secara mikro memang pembelajaran tatap muka secara langsung sangat tidak memungkinkan untuk dilakukan di tengah penyebaran pandemi Covid-19 yang semakin meluas. Maka, dibutuhkanlah perantara untuk menjembataninya agar kegiatan belajar mengajar tetap berlangsung, diantaranya adalah tidak lain dengan memanfaatkan teknologi secara maksimal. Pemanfaatan teknologi dalam sistem pembelajaran jarak jauh di sini merupakan hal baru dan memunculkan problem-problem yang bisa berdampak langsung bagi tindakan peserta didik. Untuk mengurangi dampak negatif tersebut diperlukanlah hubungan yang intens dengan model dialog antara gurupeserta didik atau guru-orang tua. Melalui dialog akan bisa memetakan masalah sampai akar rumput, sisi mana yang bisa dilakukan dan dari segi mana hal-hal yang merugikan tersebut harus dihindari. Karena selama pandemi memang belum pernah diadakan dialog, kalau pun ada hanya sedikit Madrasah Ibtidaiyah yang sudah menerapkannya itupun tentu belum maksimal.

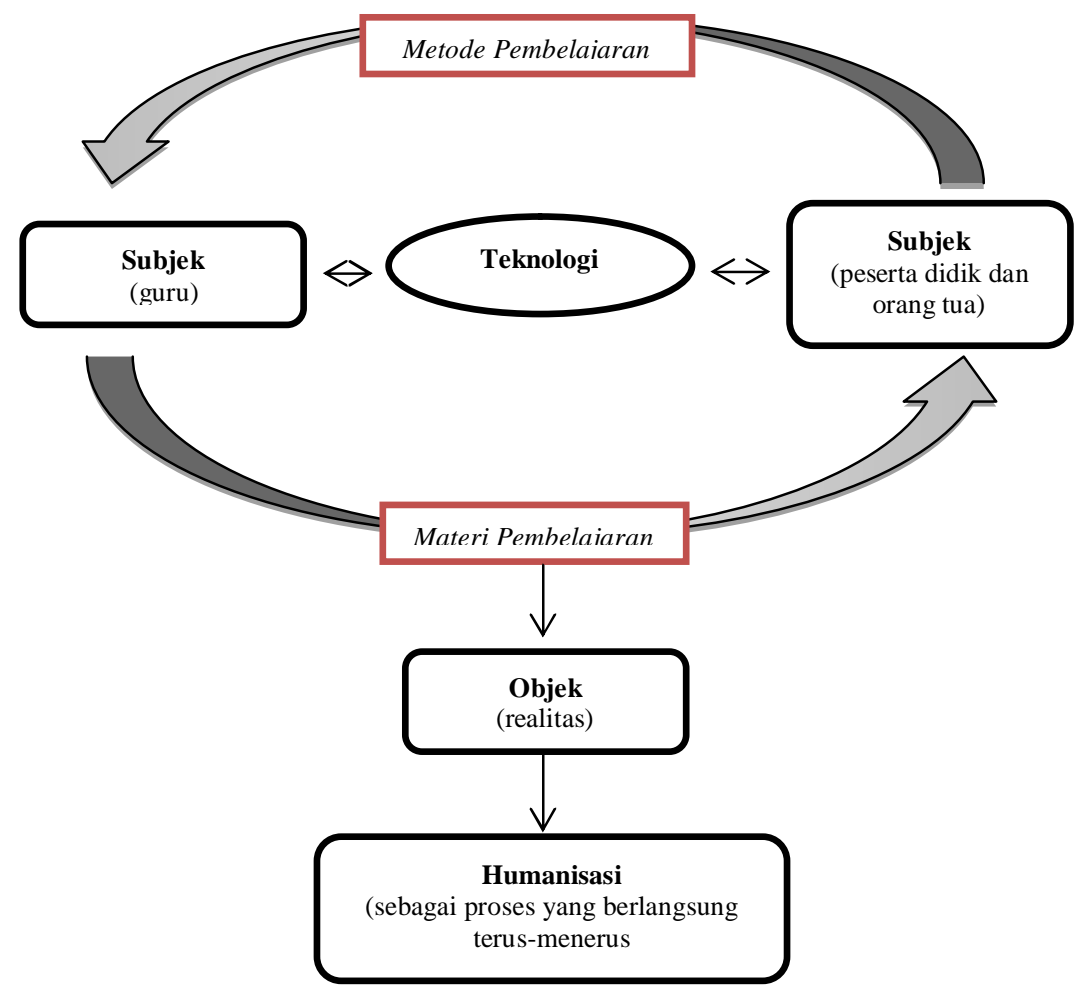

Skema 3: modifikasi sistem pembelajaran hadap masalah bebasis online 
Dengan adanya model dialog ini diharapkan tidak ada kesan lagi bahwa pendidikan telah dimonopoli oleh pihak tertentu sedangkan korbannya ada di pihak peserta didik dan tentunya orang tua yang mendampinginya juga. Hubungan yang intens antara pihak-pihak yang terlibat dalam satu sekolah bersama-sama duduk satu meja membahas persoalan aktual terkait metode pembelajaran dan materi pembelajaran hingga kendala pendidikan lainnya melalui perantara teknologi (handphone via whatsapp, facebook dan media sosial lainnya) yang menjangkau semua kalangan peserta didik.Sehingga, di sini terciptalah hubungan "subjek" dan "subjek" dengan objeknya adalah realita belajar dari rumah.Dengan demikian, teknologi bukan lagi sebagai remote kontrol pembelajaran dan pembelajaran itu sendiri sudah bukan lagi hantu yang menakuti kebebasan peserta didik dalam berekspresi. Teknologi adalah teman belajar sebagai alat bantu memperlancar arus metode pembelajaran jarak jauh. Dari sinilah proses humanitas peserta didik akan terbentuk.

\section{KESIMPULAN}

Pendidikan pada dasarnya merupakan suatu komponen yang tidak dapat dipisahkan dari kehidupan manusia. Sejak manusia dilahirkan sampai meninggal dunia terdapat suatu proses pengenalan terhadap realitas yang dihadapi. Proses pengenalan itulah disebut dengan pendidikan yang merupakan sifat murni dari manusia yang selalu ingin tahu. Pendidikan akan terus dijalaninya secara terus menerus sebagai proses menjadi (becaming) jati diri manusia seutuhnya apapun keadaannya tidak terkecuali saat merebaknya pandemi Covid-19. Penyebaran virus yang masif ini memaksa pemerintah menerapkan sejumlah protokol kesehatan diantaranya adalah himbauan belajar dari rumah. Konsep belajar dari rumah mengharuskan pihak-pihak yang terlibat dalam proses belajar mengajar (guru dan peserta didik) memaksimalkan teknologi dalam bentuk pembelajaran jarak jauh berbasis online.

Namun, satu hal yang menjadi kendala dalam penerapan pembelajaran berbasis online adalah adanya faktor kecanduan teknologi (handphone) oleh peserta didik untuk disalahgunakan diluar kepentingan pembelajaran. Selain itu, jebakan pendidikan gayabank telah menjerat proses pembelajaan di mana guru lebih memposisikan diri sebagai "subjek" dan peserta didik sebagai "objek" yang hanya menerima begitu saja perintah dari gurunya melalui pemberian tugas mandiri secara terus-menerus dengan sejumlah deadline pengumpulan akhir. Kondisi tersebut sangat tidak baik dalam proses perkembangan anak khususnya yang duduk di jenjang Madrasah Ibtidaiyah. Tujuan pendidikan secara umum harus tetap diarahkan pada pembentukan pribadi yang bermental pembebas, humanis dan demokratis malah menjadikannya sebagai pribadi yang diatur oleh remote kontrol teknologi pembelajaran.Oleh sebab itu, solusi makro dan mikro mutlak diperlukan untuk 
menghindari kemungkinan lebih buruk terjadi. Pada level makro pemerintah harus segera mengeluarkan kebijakan terbaru terkait model pembelajaran yang lebih humanis dengan penyediaan sarana dan prasarana yang mendukung. Kemudian pada level mikro diperlukan hubungan dialogis yang intens dilakukan dengan memanfaatkan teknologi secara maksimal antara guru-orang tua maupun guru-peserta didik untuk memecahkan masalah akar rumput. Logika pemikiran yang dibangun adalah usaha menjaga keberlangsungan hidup adalah hal utama dan keberlangsungan hidup itulah dapat dilakukannya pemenuhan hak atas pendidikan.

\section{DAFTAR PUSTAKA}

Alisyahbana, I. 1980. Teknologi dan Perkembangan.Jakarta: Yayasan Idayu

Adiwikarta, S. 2016. Sosiologi Pendidikan: Analisis Sosiologi Tentang Praksis Pendidikan. Bandung: Remaja Rosdakarya

Ariobimo, 2008.Bullying: Mengatasi Kekerasan di Sekolah dan Lingkungan Sekitar Anak. Jakarta: Grasindo.

Azzet, A.M. 2017. Pendidikan yang Membebaskan. Yogyakarta: Ar Ruzz Media

Damsar. 2015. Pengantar Sosiologi Pendidikan. Jakarta: Prenadamedia Group

Dzakiri, H. 2000. Islam dan Pembebasan. Jakarta: Djabatan dan Pena

Freire, P. 2008. Pendidikan Kaum Tertindas. Jakarta: Pustaka LP3ES Indonesia

Johnson, D.L. 1986. Teori Sosiologi Klasik dan Modern Jilid II. Jakarta: Gramedia

Semi, Atar. 2012. Metode Penelitian Sastra. Bandung: Angkasa Bandung

Semiawan, Conny R. 2010. Metode Penelitian Kualitatif. Jakarta: PT Grasindo

Sindhunata. 1982. Dilema Usaha Manusia Rasional: Kitik Masyarakat Modern oleh Max Horkheimer Dalam Rangka Sekolah Frankfurt. Jakarta: PT Gramedia

Singer, Dorothy dan Jerome Dorothy. 2012. Handbook of Childern and The Media. Singapura: SAGE Publications Asia-Pasific Ltd.

Siswantoro. 2005. Metode Penelitian Sastra: Analisis Psikologis. Surakarta: Muhammadiyah University Press

Switri, Endang. 2019. Teknologi dan Media Pendidikan Dalam Pembelajaran. Pasuruan: Qiara Media.

Sudarsana, I Ketut. 2020. Covid-19: Perspektif Pendidikan. Medan: Penerbit Kita Menulis. Umiarso dan Zamroni.Pendidikan Pembebasn dalam Perspektif Barat dan Timur. Yogyakarta: Ar Ruzz Media

Wirawan, I.B. 2012.Teori-teori Sosial dalam Tiga Paradigma: Fakta Sosial, Definisi Sosial, dan Perilaku Sosial. Jakarta: Kencana Prenada Media Group. 
M. S yahrul U lum, J ati P amungkas

A nal isis Kritis P ener apan metode pembelajaran berbasis onl ine di M adr asah I btidaiyah masa pandemi Covid 19 .

Zajda, Joseph dan Sev Ozdowski (Ed.). 2017. Globalisation, Human Rights, Education, and Reform. Dordrecht: Springer Nature BV.

https://www.who.int/dg/speeches/detail/who-director-general-s-opening-remarks-at-themission-briefing-on-covid-19---12-march-2020 diakses pada 5 Mei 2020

https://setkab.go.id/minta-masyarakat-tenang-presiden-saatnya-bekerja-belajar-danberibadah-dari-rumah/ diakses pada 6 Mei 2020

https://harirsilk.wordpress.com/2015/04/15/pendidikan-yang-membebaskan-menurutpaulo-freire-dalam-perspektif-pendidikan-islam/, diakses 5 Juli 2020 